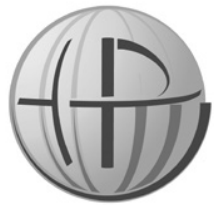

\title{
ŁUKASZ BRZEZICKI
}

http://orcid.org/0000-0002-0761-1109

Uniwersytet Gdański

brzezicki.lukasz@wp.pl

DOI: $10.35765 /$ HP.1969

Horyzonty Polityki

2021, Vol. 12, No 39

OPEN ACCESS

\section{Czy e-demokracja i rozwiązania znane ze świata biznesu są właściwymi kierunkami zmian politycznych w Polsce?}

\author{
Jest zło - widziałem je pod słońcem, \\ to błąd ze strony władcy: \\ wynosi się głupotę na stanowiska wysokie, \\ podczas gdy zdolni siedzą nisko. \\ Księga Koheleta (Eklezjastesa), 10: 5-6.
}

\section{Streszczenie}

CEL NAUKOWY: Celem artykułu jest zaproponowanie zmian obecnego systemu demokratycznego w Polsce, opartych na rozwiązaniach biznesowych i e-demokracji, poprawiających jego funkcjonowanie.

PROBLEM I METODY B AD AWCZE: Problem badawczy dotyczył rozważenia, czy wdrożenie e-demokracji oraz rozwiązań znanych ze świata biznesu może przyczynić się do ograniczenia wybranych problemów i lepszego sprawowania demokratycznej władzy, a także podwyższenia jej jakości? Podstawową metodą była zarówno analiza badań opinii publicznej o różnych aspektach polskiego systemu demokracji, jak i przegląd literatury przedmiotu dotyczącej koncepcji i teorii naukowych związanych z badaniem systemów demokratycznych.

PROCES WYWODU: W pierwszej części przedstawiono wyniki badań opinii publicznej o demokracji i jej poszczególnych obszarach działania. W drugiej części zaprezentowano koncepcje i teorie naukowe związane z badaniem systemów

Sugerowane cytowanie: Brzezicki, Ł. (2021). Czy e-demokracja i rozwiązania znane ze świata biznesu są właściwymi kierunkami zmian politycznych w Polsce? Horyzonty Polityki, 12(39), 41-66. DOI: 10.35765/HP.1969. 
demokratycznych i jego mechanizmów. Trzecia część przedstawia wybrane problemy demokracji w Polsce i propozycje ich zmian.

WYNIKI ANALIZY NAUKOWEJ: Kryzys zaufania do obecnego modelu demokracji wynika z niedopasowania jej formy do wyzwań rozwojowych. Wdrożenie zarówno koncepcji e-demokracji proponowanej przez Parlament Europejski, jak i rozwiązań znanych z świata biznesu, ogranicza wybrane problemy i przyczynia się do zwiększenia sprawności działania demokracji.

WNIOSKI, INNOWACJE, REKOMENDACJE: Pomimo ogromnej liczby publikacji w literaturze przedmiotu oraz prasie poświęconej demokracji, to przeważnie skupiano się w nich albo na ocenie obecnego stanu systemu lub jego elementów, albo teoriach naukowych związanych z danym obszarem demokracji. Sporadycznie wskazywano ad hoc propozycje zmian, jednak i wtedy miały one przeważnie charakter bieżącego reagowania na negatywne zjawiska, bez głębszego spojrzenia na cały system demokracji. W niniejszym artykule przezwyciężono powyższe ograniczenia poprzez połączenie oceny obecnego postrzegania demokracji zarówno z teorią naukowa jak i rozwiązaniami praktyki gospodarczej, które jednocześnie stanowią podstawy propozycji rozwiązań systemowych mających poprawić sprawność działania demokracji.

\section{SŁowA KLUCzowe:}

demokracja, polityka, publiczny, wybór, politycy

\section{Abstract}

\section{ARE E-DEMOCRACY AND SOLUTIONS KNOWN FROM THE BUSINESS WORLD THE RIGHT DIRECTIONS FOR POLITICAL CHANGES IN POLAND?}

RESEARCH OBJECTIVE: The aim of the article is to propose changes to the current democratic system in Poland, based on business solutions and edemocracy, improving its functioning.

THE RESEARCH PROBLEM AND METHODS: The research problem was to consider whether the implementation of e-democracy and solutions known from the world of business can contribute to the reduction of selected problems and more efficient exercise of democratic power, as well as increase its quality? The basic method was both the analysis of public opinion polls on various aspects of the Polish democracy system and a review of the literature on concepts and scientific theories related to the study of democratic systems.

THE PROCESS OF ARGUMENTATION: The first part presents the results of public opinion surveys on democracy and its individual areas of operation. 
The second section presents concepts and scientific theories related to the study of democratic systems and its mechanisms. The third section presents selected problems of democracy in Poland and proposals for their changes.

RESEARCH RESULTS: The crisis of confidence in the current model of democracy results from a mismatch between its form and development challenges. Implementation of both the concept of e-democracy proposed by the European Parliament and solutions known from the business world reduces selected problems and contributes to increasing the efficiency of democracy.

CONCLUSIONS, INNOVATIONS, AND RECOMMENDATIONS: Despite the huge number of publications in the literature and press devoted to democracy, the main focus was either on the assessment of the current state of the system or its elements, or scientific theories related to a given area of democracy. Occasionally, ad hoc proposals for change were indicated, but in this case, they were mostly, without a deeper and broad view of the entire democratic system. This paper overcomes the above limitations by combining an assessment of current perceptions of democracy with both academic theory and solutions to economic practice, which at the same time form the basis of proposals for systemic solutions to improve the efficiency of democracy.

\section{KeYwORDS:}

democracy, politics, public, choice, politicians

\section{WPROWADZENIE}

W 2019 roku minęło kilka znaczących rocznic, ważnych z punktu widzenia polskiej państwowości, m.in. rocznica polskiego parlamentaryzmu, 100-lecie pierwszych wyborów parlamentarnych w Polsce w 1919 roku oraz 30-lecie częściowo wolnych wyborów w 1989 roku. Skłaniają one do refleksji i oceny aktualnego stanu demokracji w Polsce. Z cyklicznie przeprowadzonego badania CBOS (2019a) o stanie demokracji wynika, że dla większości badanych, tj. 71\% (kwiecień 2019) demokracja ma przewagę nad wszelkimi innymi formami rządów, jednak już konkretne opinie o funkcjonowaniu demokracji w Polsce są bardzo spolaryzowane, gdyż $47 \%$ ankietowanych jest zadowolonych, a $45 \%$ niezadowolonych z jej działania. Wyrazem słabości demokracji i jakości rządzenia w Polsce jest opinia aż 29\% badanych, którzy zgadzają się z stwierdzeniem, że niekiedy rządy niedemokratyczne mogą być bardziej pożądane niż rządy demokratyczne. Takie stwierdzenie 
respondentów nie musi oznaczać sprzeciwu wobec demokracji jako takiej, ale może wskazywać na rozczarowanie, niesprawność i nieskuteczność sposobu sprawowania władzy przez elity polityczne w systemie demokratycznym. Wyborcy oczekują przede wszystkim od sfery polityki konkretnych rozwiązań, które będą służyć społeczeństwu, np. uzyskanie korzyści materialnych i niematerialnych. Rozczarowanie obywateli rządami demokratycznymi jest bardzo zróżnicowane i związane przede wszystkim $\mathrm{z}$ charakterem oraz zadaniami instytucji publicznej - oczekiwaniami społecznymi oraz częstotliwością kontaktów obywatela z tymi instytucjami lub efektami działań podejmowanych przez te instytucje. Z wyników badania CBOS (2018) można wywnioskować, że największym zaufaniem spośród instytucji publicznych cieszą się władze lokalne miasta/ gminy $(65 \%)$, a najmniejszym zaufaniem obywatele obdarzają partie polityczne (23\%). Tylko o 11 p.proc. większym zaufaniem niż partii politycznych respondenci obdarzyli Sejm i Senat. Z innego badania CBOS (2019b) wynika, że blisko połowa badanych (48\% - czerwiec 2019) ocenia negatywnie pracę Sejmu, przeciwnego zdania było $35 \%$ respondentów. W przypadku Senatu zbliżona liczba ankietowanych zarówno dobrze, jak i źle ocenia jego pracę - odpowiednio 36\% i 38\%. Zdecydowanie więcej obywateli ma problem z oceną pracy Senatu aniżeli Sejmu, gdyż odsetek osób niezdecydowanych jest większy w przypadku Senatu (26\%) niż Sejmu (17\%). Wskazywać to może, że obywatele nie widzą efektów pracy Senatu, a tym samym potrzeby istnienia tej instytucji, gdyż jej przedstawiciele są wybierani w tych samych wyborach, co do Sejmu. Z badania oceny prestiżu zawodów i funkcji społecznych (CBOS 2019d) wynika, że najmniejszym poważaniem społecznym cieszy się działacz partii politycznej (18\%), niewiele więcej uzyskał poseł na Sejm (27\%) czy minister (33\%).

Na koniec wstępnych rozważań o stanie demokracji należy również zaznaczyć, że z badań opinii publicznej wynika (CBOS 2019b), iż 67\% ankietowanych dobrze ocenia działalność Państwowej Komisji Wyborczej (PKW), jednak aż 27\% stwierdza, że „trudno powiedzieć" - podobnie, jak miało to miejsce w przypadku Senatu. Należy zauważyć, że PKW stoi na straży przeprowadzania demokratycznych wyborów i jako organ niezależny i niepolityczny powinien cieszyć się zdecydowanie wyższym zaufaniem i oceną sprawności 
działalności niż ma to miejsce. Prawdopodobnie jest to związane z nowelizacją kodeksu wyborczego i nowego sposobu wyboru przedstawicieli do składu PKW, przez co „organ wyborczy będzie w zdecydowanej większości pochodził z nadania politycznego" (Urbaniak 2018, s. 159). Ponadto większość respondentów (65\%) zapytanych o ocenę funkcjonowania demokratycznych mechanizmów i procedur wyborczych w Polsce zwraca uwagę, że telewizyjne programy informacyjne faworyzują rządzącą partię (CBOS 2019c), z czego $19 \%$ uważa, iż dzieje się tak zawsze, a $26 \%$ stwierdza, że bardzo często.

Z wyżej przytoczonych opinii społecznych wyłania się dość negatywny obraz demokracji, w której przedstawiciele społeczeństwa są traktowani jak zło konieczne, a ocena ich pracy jest przeważnie wyrażana $w$ kategoriach negatywnych. Nie można nie zgodzić się z Jerzym Wilkinem (2012a, s. 281), który stwierdza, że „poprawa jakości rządzenia stanowi więc dla naszego kraju kwestię priorytetową". Instytucje demokratyczne (np. Sejm i Senat) i inne organy wspierające (np. PKW), ale również media nie funkcjonują do końca dobrze. $W$ związku z powyższym należy uznać, że obecny model demokracji i sprawowania władzy daleki jest od ideału i oczekiwań społecznych. Głównym powodem negatywnej oceny demokracji są źle oceniani reprezentanci społeczeństwa, którzy tworzą pejoratywne ramy prawno-ekonomiczne dla społeczeństwa, ale również prawno-organizacyjne dla instytucji publicznych. Dlatego w dalszej części zostanie na nich w głównej mierze skupiona uwaga. Celem artykułu jest zaproponowanie zmian obecnego systemu demokratycznego w Polsce, opartych na rozwiązaniach biznesowych i e-demokracji, poprawiających jego funkcjonowanie. Motywacją autora do podjęcia się omawianej problematyki było znamienne sformułowanie znajdujące się w recenzji do publikacji Teoria wyboru publicznego. Wstęp do ekonomicznej analizy polityki i funkcjonowania sfery publicznej z 2005 roku pod redakcją J. Wilkina, w której Dariusz Grzybek wskazuje, iż

można mieć też nadzieję, że praca warszawskich uczonych będzie punktem wyjścia do dalszych prac krytycznych i twórczych, rozwijających idee z kręgu teorii wyboru publicznego (Grzybek, 2007, s. 173). 


\section{PRZEGLĄD LITERATURY}

Autorzy zajmujący się analizą demokratycznych systemów zarządzania państwem stworzyli i rozwinęli wiele różnych teorii, koncepcji i modeli, mających zbadać i wyjaśnić m.in. sposób wyboru przedstawicieli wyborców, podejmowanie decyzji w społeczeństwie w zakresie podziału ograniczonych zasobów oraz mechanizmy ich przepływu między różnymi stronami społeczeństwa, a także możliwości ich racjonalnego wykorzystania. Wśród wielu dostępnych w literaturze przedmiotu teorii i koncepcji związanych z demokracją i systemem sprawowania władzy w państwie znajdują się takie, które są powiązane z celem niniejszego artykułu. Dla usystematyzowania warto przytoczyć kilka z nich, a mianowicie: teorię wyboru publicznego, teorię wyboru społecznego, ekonomiczną teorię demokracji Anthony'ego Downsa, ekonomiczną teorię regulacji, ekonomię konstytucyjna, ekonomiczną teorię prawa, teorię grup interesu Mancura Olsona, nową ekonomię instytucjonalną oraz nową ekonomię polityczną. Ponadto Wilkin (2012c, s. 29) wskazuje, że „rozwijają się też nurty badawcze na styku różnych dyscyplin nauk społecznych, które mają duże znaczenie dla teorii wyboru publicznego", jaką jest m.in. ekonomia behawioralna. Ten sam autor (Wilkin, 2012c, s. 11) sugeruje, że

ekonomiści zainteresowali się polityka, jej instytucjami i mechanizmami wyboru z co najmniej dwóch powodów: w sferze tej wykorzystuje się dużą część zasobów i wytwarzanego Produktu Krajowego Brutto (30-60\%), a także zwraca uwagę na decyzje polityczne, które kształtują ład instytucjonalny i inne ważne warunki, w jakich prowadzona jest działalność gospodarcza.

Uwagi krytyczne kierowane w stosunku do teorii wyboru publicznego (Hauptmann, 1996) czy innych teorii i koncepcji są naturalną konsekwencją prowadzonego dyskursu naukowego, który ma na celu poszukiwanie najlepszych rozwiązań. Na podstawie tych rozważań modyfikowane są obecne i tworzone nowe teorie i koncepcje. Warto również zaznaczyć, że coraz większa złożoność procesów społeczno-ekonomicznych, a także przenikanie się działalności cyfrowej i realnej wpływa wieloaspektowo na sposób funkcjonowania systemu demokracji. Dlatego klasyczne podejście badawcze dotyczące 
demokracji coraz częściej ustępuje interdyscyplinarnemu, które łączy w sobie wiedzę z wielu dziedzin nauki. Przykładem takiej konwencji badawczej może być publikacja Contucci i in. (2019). Niniejsza praca również wpisuje się w ten nurt badawczy.

Należy w tym miejscu podkreślić, że celem tej części jest wyłącznie przedstawienie teoretycznych podstaw w zakresie różnych teorii, koncepcji i modeli związanych z systemem demokratycznym, będących jedynie punktem odniesienia dla autorskich propozycji zmian demokracji przedstawionych $w$ dalszej części artykułu. Intencją autora jest zatem uwypuklenie pojedynczych zagadnień ugruntowanych $\mathrm{w}$ literaturze przedmiotu, które posłużą w dalszej części do zaproponowania rozwiązań praktycznych opartych na omawianych podstawach teoretycznych.

W rozwoju gospodarczym bardzo często nie docenia się roli i znaczenia instytucji, które przyczyniają się do skutecznej realizacji przyjętej polityki publicznej. W literaturze (Legiędź, 2013) wskazuje się, że odpowiedzią na te mankamenty jest nowa ekonomia instytucjonalna, która stara się włączyć instytucje do ekonomii. Jak się okazuje badanie instytucji może być kluczem do zrozumienia rozwoju gospodarczego $\mathrm{w}$ różnych krajach.

Teoria wyboru publicznego, opierając się na nowej ekonomii instytucjonalnej i teorii gier, wyjaśnia proces kształtowania instytucji w sferze polityki i poszukuje rozwiązań instytucjonalnych, które minimalizują koszty transakcyjne (Przesławska, 2006). Jakość instytucji decyduje zarówno o sprawności oraz efektywności funkcjonowania sfery politycznej, jak i sfery ekonomicznej (Wilkin, 2012c, s. 11). Cechą charakterystyczną teorii wyboru publicznego jest to, że

zastosowuje zasady standardowej analizy ekonomicznej do sfery zjawisk nierynkowych lub quasi-rynkowych. Na tę sferę zainteresowań teorii wyboru publicznego składają się przede wszystkim obszar decyzji politycznych, kształtowanie się porządku publicznego i mechanizm dostarczania dóbr publicznych. Teoria bada instytucjonalne uwarunkowania mechanizmu osiągania korzyści ekonomicznych poprzez proces polityczny „na rynku politycznym” (Wilkin, 2012c, s. 21).

Przedstawiając teorie wyboru publicznego nie sposób nie wymienić politycznej pogoni za rentą czy niesprawności (zawodności) państwa. Polityczna pogoń za rentą jest 
formą korzyści związanej z wykorzystaniem ograniczonych zasobów (pracy i kapitału) do działalności, która nie zwiększa ilości produktów ani usług, służących poprawie dobrobytu społecznego. Korzyści, występujące w postaci renty politycznej, są jedynie formą transferu dochodów od jednych podmiotów do innych przy wykorzystaniu władzy politycznej (Wilkin, 2012b, s. 222-223).

Pogoń za rentą polityczną powoduje negatywne skutki ekonomiczne i prowadzi do utrzymywania się PKB poniżej możliwości produkcyjnych kraju, gdyż część zasobów renty nie zostaje spożytkowana produkcyjnie, na skutek czego pogarsza się efektywność alokacji zasobów gospodarczych, jak i skutki społecznie, bowiem w sposób systemowy deformuje się mechanizm polityki oraz kulturowo-normatywną tkankę społeczeństwa i wzmacnia brak poczucia sprawiedliwości (Zybertowicz, 2010; Przesławska, 2006). Niesprawność państwa występuje $\mathrm{w}$ rzeczywistym świecie podobnie jak niesprawność rynku, która jest jednak częściej analizowana w literaturze przedmiotu niż zawodność sfery publicznej. Według Josepha E. Stiglitza (2004) są cztery główne przyczyny zawodności państwa (Bochenek, 2010): ograniczony zasób dostępnej informacji, ograniczona kontrola nad skutkami działań państwa na prywatnych rynkach, ograniczona kontrola nad biurokracją i ograniczenia o charakterze politycznym obejmujące poczynania rządu, których realizacje są uzależnione od decyzji politycznych.

W literaturze nauk społecznych oprócz teorii wyboru publicznego jest rozwijany nurt wyboru społecznego, który według Grzegorza Lissowskiego (2010, s. 5)

zajmuje się warunkami nakładanymi na sposoby realizacji pożądanych dla społeczeństwa rozwiązań, przy ustalonych preferencjach i użytecznościach członków grupy lub społeczeństwa. Zadanie tej teorii może być jednak sformułowane również ogólniej - badanie teorii normatywnych, które wskazują jakie rozwiązania są bardziej pożądane ze społecznego punktu widzenia.

Następnym nurtem badawczym służącym objaśnieniu mechanizmu zachowania wyborców i partii politycznych w warunkach demokratycznej konkurencji jest ekonomiczna teoria demokracji. Zaproponowany przez Downsa model zakłada, że demokracja jest swojego rodzaju rynkiem politycznym, a podmioty polityczne, tj. wyborcy 
i politycy, kierują się przede wszystkim racjonalnością wyboru oraz zasadą maksymalizacji swoich indywidualnych korzyści, a nie altruizmem (Sell i Tkaczyński, 2011). Oznacza to, że „politycy formułują programy polityczne w celu zdobycia władzy" (Przesławska, 2006, s. 39), która przyniesie im korzyści zarówno materialne, jak i niematerialne, „,a nie dążą do władzy w celu wprowadzenia programów politycznych" (Przesławska, 2006, s. 39) jako takich, jednak ignorowanie woli wyborców przez dłuższy czas może spowodować ich ukaranie i nie wybranie w kolejnych wyborach. Zatem choć część programu wyborczego musi być przez nich zrealizowana. Natomiast „prospołeczne zachowania rządu wymusić mogą jedynie instytucje i mechanizmy ograniczające polityków w ich prywatnych dążeniach (włącznie z wyborem nowego rządu przez społeczeństwo)" (Przesławska, 2006, s. 39). W modelu Downsa wyborca jest racjonalną jednostka, która podejmuje decyzje o udziale w wyborach, biorąc pod uwagę przede wszystkim bieżące zróżnicowanie partii oraz porównanie kosztów i oczekiwanych korzyści, jakie może uzyskać. Jednak wyborcy częstokroć odczuwają niepewność co do odpowiedniego wyboru, gdyż nie mają lub nie są w stanie przetworzyć wszystkich niezbędnych informacji, aby zrozumieć programy wyborcze i przewidzieć skuteczność ich realizacji, dlatego zamiast analizy merytorycznej przechodzą do oceny partii na podstawie ideologii, która pozwala im szybciej dokonać rozróżnienia między partiami. Natomiast partiom pozwala to wzmacniać zjawisko przywództwa, czyli takiego wpływania na wyborców, aby przyjmowali opinie partii jak swoją własną. Oznacza to, że wyborcy w warunkach niepewności, trudności w dostępie i zrozumieniu programów wyborczych, bez skondensowanych i rzetelnych informacji podejmują decyzje na podstawie swoich przeczuć i ideologicznego zróżnicowania partii. Mimo wszystko wyborcy starają się czerpać informacje o partiach i programach wyborczych od innych podmiotów (np. mass mediów), jednak zawsze jest to informacja przetworzona (Michalak, 2012).

Z uwagi, że rynek polityczny charakteryzuje się dużą asymetrią informacji, a jej indywidualne pozyskiwanie i przetwarzanie jest kosztowne oraz czasochłonne, grupy interesu stosują swoje wewnętrzne mechanizmy koordynacji i wymiany, przez co mają przewagę nad niedoinformowanymi wyborcami. Wykorzystują skuteczniej presję polityczną niż społeczeństwo jako całość, dążąc do 
zaspokojenia własnych potrzeb kosztem innych grup. Wskazuje to, że działanie grup interesu nie jest korzystnym zjawiskiem dla kraju, gdyż skutkuje nieefektywnością sfery gospodarczej. W odróżnieniu od nich partie $\mathrm{w}$ zinstytucjonalizowanej formie rywalizują na rynku politycznym o zdobycie bezpośredniej władzy i podejmowania decyzji formalnie wpływających na społeczeństwo. Grupy interesu dążą natomiast do maksymalizacji wpływu na władzę publiczną bez konieczności jej zdobywania i rywalizowania na rynku politycznym, przez co zachowują status podmiotów apolitycznych, które reprezentują oraz promują interesy poszczególnych grup społecznych (Ogonowski, 2018). Jednak zgodnie $z$ teorią przedstawioną przez Olsona, odnośnie do ekonomicznej analizy formowania się grup interesu i indywidualistycznego podejścia do współdziałania grupowego, wynika że "przesłanką kolektywnego działania na arenie politycznej nie jest wspólny cel grupy, a partykularne interesy liderów grupy" (Przesławska, 2006, s. 41). Olson stwierdza wprost, że

w rzeczywistości, jeśli liczba jednostek w grupie nie jest znikoma i nie funkcjonują w niej specjalne mechanizmy wymuszające na członkach działanie w interesie wspólnym, racjonalne, zorientowane na interes własny jednostki nie podejmą działań dla osiągnięcia wspólnego, czyli grupowego celu (Olson, 2012, s. 10).

Jak słusznie z kolei zauważa Wilkin (2012c, s. 25):

koncepcja Olsona, podobnie jak reprezentantów teorii pogoni za rentą podważa twierdzenie charakterystyczne dla sporego odłamu przedstawicieli teorii wyboru publicznego, że polityczny rynek demokracji jest dobrą płaszczyzną efektywnego transferu bogactwa.

Ponadto warto zaznaczyć, że

Olson opracował, $\mathrm{w}$ ramach teorii wyboru publicznego, teorię wzrostu gospodarczego. Teoria ta zakłada, że wyższe tempo wzrostu gospodarczego wymuszają radykalne zmiany społeczne i polityczne. Zmiany te zwiększają bowiem elastyczność struktury społecznej, pozbawiając wpływów grupy interesu. $Z$ teorii tej wynika więc, że polityczna stabilność umacnia negatywny wpływ lobbies na politykę gospodarczą rządu (Przesławska, 2006, s. 41-42). 
Nowa ekonomia polityczna, jak wskazuje Przesławska (2006, s. 35),

obejmuje teorię wyboru publicznego i teorię cykli politycznych oraz próbuje wyjaśnić zmiany struktury instytucji pod wpływem konkurencji między jednostkami i organizacjami na rynku politycznym.

Polityczny cykl koniunkturalny związany jest z współzależnością między dynamiką polityki gospodarczej kraju a dynamiką sytemu politycznego (wyborczego). Oznacza to, że w zależności od cyklu wyborczego, tj. przed lub po wyborach, polityka gospodarcza albo ma charakter ekspansji, albo recesji (Przesławska, 2006).

Kolejne trzy teorie związane są m.in. prawnymi uwarunkowaniami sprawowania władzy w systemach demokratycznych oraz oceną podejmowanych przez nich decyzji wpływających na sferę społeczno-ekonomiczną. Pierwszą z nich jest ekonomia konstytucyjna, która stanowi próbę

wyjaśnienia właściwości działań alternatywnych zestawów prawno-instytucjonalno-konstytucyjnych reguł ograniczających wybory i działania aktorów ekonomicznych i politycznych oraz określających ramy, w których dokonują oni zwykłych wyborów (Metelska-Szaniawska, 2012, s. 110).

W ramach tej teorii wyróżnia się dwie gałęzie badawcze, z których pierwsza dotyczy legitymizacji działań publicznych i jej przedstawicieli, a druga analizy i modyfikacji reguł konstytucyjnych oraz oceny skutków jej istnienia (Metelska-Szaniawska, 2012). Drugim programem badawczym jest natomiast ekonomiczna analiza prawa, która polega na zastosowaniu

teorii ekonomii i właściwych jej narzędzi do badania, tworzenia, struktury, procesów i znaczenia prawa, przy czym jest ono analizowane nie jako element egzogeniczny wobec systemu gospodarczego, ale jako jego zmienna wewnętrzna (Guzik, 2017, s. 31).

Trzecią koncepcją jest ekonomiczna teoria regulacji, która polega na wykorzystaniu różnych narzędzi prawnych w celu osiągnięcia zakładanych efektów społeczno-ekonomicznych. W jej ramach można wyróżnić dwa nurty badawcze, z których pierwszy dotyczy analizy regulacji pod względem efektywności lub optymalności rozwiązania, 
a drugi wyjaśnienia regulacji prawnych oraz badania skutków ich wprowadzania i funkcjonowania (Metelska-Szaniawska i Olender-Skorek, 2012). W kontekście powyższych koncepcji szczególnego znaczenia nabiera ekonomia behawioralna, która jest swoistym połączeniem dokonań ekonomii z psychologią.

Większość z przedstawionych powyżej teorii i koncepcji zostało sformułowane na podstawie zaobserwowanych reguł w funkcjonujących wówczas systemach demokratycznych, które były i dalej są dalekie od doskonałości. Jednak postęp społeczno-ekonomiczny sprawia, że dostępne są obecnie nowe możliwości i szanse rozwojowe, które uprzednio nie były przez wielu autorów w ogóle brane pod uwagę. W związku z powyższym, istnieje ogromna potrzeba przedstawienia propozycji zmian systemu demokratycznego, biorąc pod uwagę współczesne uwarunkowania i możliwości cywilizacyjne, tak aby system zarządzania państwem był skuteczniejszy i efektywniejszy w stosunku do obecnego.

\section{NIEDOSKONAŁOŚCI OBECNEGO SYSTEMU I PROPONOWANE KIERUNKI ZMIAN}

Z danych przytoczonych w pierwszej części artykułu można wywnioskować, że utrzymuje się kryzys zaufania do demokracji przedstawicielskiej, objawiający się osłabieniem zaufania do elit politycznych, sprawności systemu demokratycznego jako takiego, czy jego możliwości skutecznej, racjonalnej i efektywnej redystrybucji dobrobytu społecznego. W literaturze wskazuje się, że

teoretycy, i historycy demokracji podkreślają że jej koncepcje oraz wynikające $\mathrm{z}$ nich rozwiązania instytucjonalne podlegają charakterystycznej ewolucji. [...] Co jakiś czas pojawiał się również problem kryzysu demokracji, który jak się potem okazywało dotyczył jej konkretnych koncepcji, a zwłaszcza praktycznej ich realizacji. Kryzysy demokracji najczęściej towarzyszyły bądź były jedną z przyczyn ogólnych kryzysów systemów, bądź niedopasowania jej form do wyzwań rozwojowych. Stawały się one jednocześnie impulsem do poszukiwania nowych form demokracji, nowych jej instytucji" (Gilejko, 2012, s. 59). 
W konsekwencji można postawić następujące pytania. Czy obecna formuła demokracji funkcjonującej w Polsce nie wyczerpała się? Czy jej postać odzwierciedla rozwój cywilizacyjny? Czy odpowiada na oczekiwania społeczeństwa i wyzwania rozwojowe? O potrzebie zmian obecnej formy demokracji i dostosowanej jej do wymagań współczesności wskazuje się od kilku lat w światowej literaturze. Warto chociażby przytoczyć pracę Pii Mancini (2015, s. 69), w której występują następujące stwierdzenia:

Współczesne systemy polityczne nie są zsynchronizowane z czasami, w których żyjemy. Choć internet umożliwia nam bezprecedensowy dostęp do informacji, niskie koszty współpracy i uczestnictwa, a także możliwość wyrażania naszych pragnień, żądań i obaw, nasz wkład w kształtowanie polityki ogranicza się do głosowania raz na dwa do pięciu lat. Innowacyjne narzędzia, zarówno online, jak i offline, są potrzebne, aby ulepszyć nasze demokracje. Społeczeństwo potrzebuje instrumentów i procesów, które pozwolą mu decydować o tym, jak jest rządzone. Należy ustanowić instytucje, które odzwierciedlają dzisiejsze realia i wartości technologiczne, kulturowe i społeczne.

Pośrednio w odpowiedzi na kryzys zaufania obywateli do obecnego modelu demokracji przychodzi stanowisko Parlamentu Europejskiego, który 16 marca 2017 roku przyjął rezolucję dotyczącą e-demokracji w Unii Europejskiej, podkreślającą potencjalne korzyści płynące z e-demokracji. Natomiast ją samą definiuje się jako wsparcie i wzmocnienie demokracji tradycyjnej za pomocą technologii informacyjno-komunikacyjnej (ICT), która może uzupełniać i wzmacniać procesy demokratyczne przez dodanie elementów służących wzmocnieniu pozycji obywateli, dzięki różnym działaniom online, obejmującym m.in. administrację elektroniczną, e-rządzenie, e-debaty, e-uczestnictwo i e-głosowanie. Warto podkreślić, że celem e-demokracji jest propagowanie kultury demokratycznej, która ubogaca i wzmacnia praktyki demokratyczne przez zapewnianie dodatkowych środków zwiększających przejrzystość i uczestnictwo obywateli. Celem e-demokracji nie jest zatem ustanowienie alternatywnego systemu demokratycznego ze szkodą dla demokracji przedstawicielskiej, dlatego działania na rzecz e-demokracji należy połączyć z równoczesną działalnością skierowaną do tradycyjnych środowisk sprzyjających uczestnictwu obywateli w życiu politycznym. Ponadto w rezolucji zwraca się uwagę na e-uczestnictwo jako 
kluczowy element charakterystyczny dla e-demokracji. Obejmuje ona trzy formy interakcji między rządami z jednej, a obywatelami z drugiej strony, tj.: e-informacje, e-konsultacje i elektroniczne podejmowanie decyzji. Oznaczać to może wykorzystanie elementów demokracji bezpośredniej przez obywateli za pomocą narzędzi i możliwości, jakie daje internet $\mathrm{i}$ związane $\mathrm{z}$ nim technologie. Warty odnotowania jest fakt, że w rezolucji stwierdzono, iż wiele krajowych, regionalnych i lokalnych przypadków e-uczestnictwa może być uważanych za dobre przykłady wykorzystania ICT w demokracji uczestniczącej, zatem zachęca się państwa członkowskie do dalszego rozwijania takich praktyk na szczeblu krajowym i lokalnym.

W literaturze można znaleźć krytyczne publikacje odnoszące się do e-demokracji (np. Hindman, 2009). Istotne argumenty prezentują zarówno jej oponenci, jak i popularyzatorzy - główne wady i zalety e-demokracji przedstawiono w tabeli poniżej. Należy zaznaczyć, że e-demokracja ma jedynie wspierać tradycyjną demokrację, a nie ją zastąpić, więc część negatywnych opinii kierowana pod jej adresem jest w ocenie autora na wyrost, gdyż wskazują one na rozważane, teoretyczne, bądź mało istotne, a nie rzeczywiste problemy. Jednak obserwując kierunek rozwoju cywilizacyjnego ludzkości nie można zanegować wpływu ICT na obecne przemiany w różnych aspektach, m.in. ekonomicznych, społecznych i kulturowych (Carayannis, 2014). Idea e-demokracji nie jest oderwanym zagadnieniem czy postulatem, ale wpisuje się w szerszy megatrend - czwartą rewolucję przemysłową (tzw. przemysł 4.0.), w której zwraca się uwagę na wykorzystanie nowych technologii cyfrowych i komunikacyjnych między urządzeniami a ludźmi w różnych aspektach działalności społeczno-ekonomicznej (Tvaronaviciene i Burinskas, 2020). Odnosi się zatem do integracji systemów i tworzenia sieci powiązań między nimi. Dlatego należy przypuszczać, że koncepcja e-demokracji będzie dalej rozwijana mimo wielu potencjalnych zagrożeń (Barth i Schlegelmilch, 2014), a jej elementy coraz częściej poddawane będą badaniu (Lindner i Aichholzer, 2020). W kontekście e-demokracji i jej popularyzacji warto zwrócić uwagę na interesujący nurt badawczy, a mianowicie wykorzystania komputerowych gier strategicznych o demokracji (np. „Democracy 4”, , Realpolitiks II”, ,New Shores a Game for Democracy"), z jednej strony jako narzędzia edukacyjnego mającego uatrakcyjnić partycypację obywatelską i wpływać 
na kreowanie odpowiednich postaw obywatelskich, a z drugiej jako rozwiązania badawczego do przeprowadzania symulacji i eksperymentów w zakresie zmian systemu demokracji (Lerner, 2014), jakie mogą być realizowane $w$ ramach np. ekonomii behawioralnej czy ekonomii eksperymentalnej.

Tabela.

Wady i zalety e-demokracji

\begin{tabular}{|c|c|}
\hline Wady & Zalety \\
\hline $\begin{array}{l}\text { 1. Nie każdy obywatel skorzysta } \\
\text { z narzędzi e-demokracji z powodu: } \\
\text { a) wykluczenia cyfrowego (braku } \\
\text { dosteppu do internetu oraz braku } \\
\text { urządzeń komunikacji cyfrowej), } \\
\text { b) braku umiejętności cyfrowych, } \\
\text { c) braku zaufania do nowoczesnych } \\
\text { technik komunikacji elektronicznej, } \\
\text { d) modelu zachowań } \\
\text { i preferencii osobistych } \\
\text { (np. myślenie o wyższości } \\
\text { głosowania stacjonarnego nad } \\
\text { elektronicznym). } \\
\text { 2. Problemy informatyczne } \\
\text { (oprogramowania i sprzętu): } \\
\text { a) zawodność sprzętu } \\
\text { komputerowego (awarie: } \\
\text { komputerów, serwerów itp.), } \\
\text { b) zawodność oprogramowania (np. } \\
\text { błędny algorytm zliczania głosów, } \\
\text { transparentnóś rozwizazania } \\
\text { informatycznego, tzn. jego kod } \\
\text { w jezzyku programowania). } \\
\text { 3. Zabezpieczenia cyfrowe: } \\
\text { a) anonimowość (tajność) oddania } \\
\text { głosu, } \\
\text { b) problem głosowania za kogoś } \\
\text { (np. po zainfekowaniu komputera } \\
\text { i przejęcia nad nim kontroli), } \\
\text { c) cyfrowa kradzież wyników } \\
\text { głosowania przed ich oficjalnym } \\
\text { udostępnieniem, } \\
\text { d) manipulowanie globalnymi } \\
\text { wynikami głosowań przez } \\
\text { hakerów (np. przez państwa } \\
\text { nieprzychylne). } \\
\text { 4. Ograniczona kontrola dobrowolności } \\
\text { oddania głosu (np. poprzez zmuszenie, } \\
\text { zastraszenie lub przekupstwo danej } \\
\text { osoby). }\end{array}$ & $\begin{array}{l}\text { 1. Szybsze uzyskiwanie wyników } \\
\text { ggosowania. } \\
\text { 2. Ułatwienie dla osób } \\
\text { z niepełnosprawnościa } \\
\text { (zgłaszania e-petycji, uczestnictwa } \\
\text { w e-głosowaniu itd. Nie zawsze } \\
\text { stacjonarny lokal wyborczy } \\
\text { jest przystosowany dla osób } \\
\text { z niepełnosprawnością - } \\
\text { niedostępność architektoniczna } \\
\text { obiektów). } \\
\text { 3. Łatwy i mniej kosztowny proces } \\
\text { informowania obywateli o działaniach } \\
\text { władzy poprzez darmowe } \\
\text { ogólnodostępne serwisy internetowe } \\
\text { (np. strony www, twitter itp.). } \\
\text { 4. Mniejsze koszty e-głosowania } \\
\text { w stosunku do jej stacjonarnej } \\
\text { formy (redukcja kosztów wydruku, } \\
\text { dystrybucji, liczenia i wprowadzania } \\
\text { danych do systemu elektronicznego, } \\
\text { liczby pracowników). }\end{array}$ \\
\hline
\end{tabular}




\begin{tabular}{|c|c|}
\hline 5. Negatywne zjawiska elektroniczne, & 5. Łatwa i intuicyjna obsługa narzędzi \\
które mogą wpływać na zachowania & e-demokracji (np. e-głosowania). \\
obywateli i ich decyzje wyborcze: & 6. Możliwość szybszej modyfikacji \\
a) fake news (nieprawdziwa lub & i elastycznego dostosowania platform \\
częściowo nieprawdziwa & elektronicznych do bieżącej sytuacji. \\
wiadomość), & 7. Zredukowanie do minimum głosów \\
b) farmy trolli (firmy zajmujące się & nieważnych (jedynie błędy techniczne \\
masowym rozpowszechnianiem & mogą powodować nieważność \\
określonych treści zleconych przez & oddanych głosów, np. przerwanie \\
zleceniodawcę, wpływających & połączenia internetowego). \\
na postrzeganie rzeczywistości & 8. Oddanie głosu w formie \\
i zmianę zachowań ludzkich. & elektronicznej w dowolnym miejscu, \\
Często ingerują w sprawy & wpłynie na wzrost frekwencji \\
polityczne, światopoglądowe itd.), & wyborczej. \\
c) flaming (celowe wzbudzanie & 9. Redukcja części biurokracji \\
negatywnych reakcji u innych & wyborczej poprzez generowanie \\
użytkowników), & danych z publicznych systemów \\
d) mowa nienawiści (hejt). & bazodanowych. \\
6. Jednorazowe wysokie koszty & 10. Wzmocnienie społeczeństwa \\
stworzenia i wdrożenia systemu & obywatelskiego (łatwiejsze i szybsze \\
informatycznego obsługującego & wysuwanie inicjatyw obywatelskich). \\
różne narzędzia e-demokracji & 11. Możliwość przeprowadzenia \\
(np. e-głosowania). & głosowań nawet w sytuacjach \\
& nadzwyczajnych (np. klęsk \\
& żywiołowych, pandemii itd.). \\
& 12. Większa transparentność oraz \\
& możliwość kontrolowania i rozliczania \\
działań politycznych. \\
\hline
\end{tabular}

Źródło: opracowanie własne.

Z danych GUS (2019a; 2019b) wynika, że stale wzrasta liczba osób korzystających z usług publicznych za pomocą internetu. Należy jednak podkreślić, że wszystkie projektowane i wdrożone e-usługi (np. e-PIT, ePUAP, PUE ZUS, ZIP NFZ itd.) dotyczą jedynie administracji publicznej (Ministerstwo Cyfryzacji, 2020), a nie procesu wyborczego, co jest zasadniczym problemem i ograniczeniem e-demokracji. Wdrożenie zarówno zasad zgodnych z duchem Parlamentu Europejskiego, jak i sprawdzonych rozwiązań znanych ze świata biznesowego, pozwala ograniczyć wiele ułomności obecnego systemu oraz stwarza wiele szans przyspieszających rozwój społeczno-ekonomiczny kraju w krótszym czasie, ale również umożliwia zmianę samej formy i sposobu funkcjonowania demokracji przedstawicielskiej (pośredniej), o czym będzie mowa w dalszej części artykułu.

Obecnie można elektronicznie wyrażać swoją wolę w stosunku do administracji publicznej w postaci kierowania wniosków i opinii (np. ePUAP), a także spełniać obowiązki obywatelskie w postaci 
płacenia i rozliczania elektronicznego podatków (e-PIT), dlatego nie można znaleźć merytorycznego uzasadnienia, aby obywatel nie mógł elektronicznie głosować w wyborach politycznych, które są filarem demokracji. Tym bardziej, że z przeprowadzonych badań przez Magdalenę Musiał-Karg (2020) wynika, iż Polacy przychylnie odnoszą się do możliwości elektronicznego głosowania.

Pierwszym i zarazem głównym postulatem jest wprowadzenie możliwości głosowania elektronicznego oprócz obecnej standardowej formy osobistego oddania głosu w lokalu wyborczym. Warto w tym miejscu podkreślić, że elektroniczne głosowanie zostało wdrożone w Estonii już w 2005 roku i stale zyskuje na popularności wśród obywateli (Musiał-Karg, 2020). Drugim użytecznym rozwiązaniem łączącym tradycyjne i elektroniczne głosowanie byłoby ustawienie w lokalach wyborczych maszyn (terminali) do głosowania (Musiał-Karg, 2020). Podobne rozwiązanie stosowane jest m.in. od wielu lat $\mathrm{w}$ jednostkach samorządu terytorialnego (JST) czy innych instytucjach publicznych, a także $\mathrm{w}$ bankach, które mają za zadanie ukierunkować obywatela i wyznaczyć tzw. miejsce w kolejce. Wdrożenie zarówno głosowania elektronicznego przez internet, jak i ustawienie terminali do głosowania w lokalach wyborczych, rozwiązałoby w części problem długiego oczekiwania na wyniki wyborów, przyspieszając proces ich publikacji.

Z wyborami politycznymi nierozerwalnie jest związana PKW, która po wprowadzeniu elektronicznego głosowania powinna nie tylko rejestrować partie polityczne, ale też pełnić funkcję agregatora (porównywania ofert biznesplanów politycznych według przyjętych wspólnych kryteriów, co będzie wyjaśnione w dalszej części artykułu) i dostarczyciela rzetelnych informacji o partiach politycznych. Po pierwsze $\mathrm{w}$ celu zmniejszenia asymetrii informacji w społeczeństwie, a po drugie - zmniejszenia barier wejścia nowych partii na rynek polityczny. Obywatele muszą mieć szybki dostęp do szczegółowych i porównywalnych informacji o partiach i ich biznesplanach politycznych. Idea praktycznego porównywania funkcjonuje w sieci internetowej od wielu lat, warto chociażby wspomnieć o porównywarkach cenowych, ofert czy produktów w serwisach i sklepach internetowych, z których często korzystają użytkownicy. Wystarczyłoby wdrożyć podobne rozwiązanie na stronie internetowej PKW, dostosowując je do specyfiki wyborczej i politycznej. Obecnie partie polityczne tworzą 
programy polityczne, które są dalekie od realnych i rzetelnych dokumentów strategicznych czy operacyjnych, bowiem nie opierają się na danych. Nie mają sprecyzowanego harmonogramu ani zakresu czasowego bądź merytorycznego, stanowią jedynie ogólne życzenia pretendujących do władzy ustawodawczej. W związku z powyższym nie są użytecznym narzędziem zarządczym. Wracając do wcześniejszych teorii demokracji, w których scena polityczna jest specyficznym rynkiem politycznym, a stosując analogie do wolnorynkowego mechanizmu gospodarowania - podmiot gospodarczy rozpoczynając działalność tworzy biznesplan, w którym są zawarte ściśle określone uwarunkowania, wyliczenia i kierunki rozwoju przedsiębiorstwa. W związku z powyższym należy przyjąć, że byłby on również użytecznym narzędziem zarządczym na scenie politycznej oraz umożliwiającym obywatelom zarazem ocenę danej partii w trakcie wyborów, jak i podczas sprawowania przez nich władzy.

Polityczny biznesplan powinien opierać się, podobnie jak biznesplan gospodarczy, na danych, wyliczeniach i możliwych scenariuszach podejmowanych działań. Po pierwsze, powinien dotyczyć przede wszystkim głównych zagadnień, jak np. system podatkowy, przedsiębiorczość itd. Po drugie, winien przedstawiać możliwe rozwiązania $w$ trzech wariantach (negatywnym, neutralnym, pozytywnym) oraz dotyczyć terminu krótko- i średniookresowego. Takie podejście wymusi na partiach politycznych nie tylko dbanie o popularność w krótkim okresie, jak jest dotychczas, ale również myślenie i podejmowanie decyzji strategicznych, które mogą być niepopularne w społeczeństwie, ale konieczne do wdrożenia. Natomiast ocena skuteczności i efektywności przyjętej strategii rządzenia i realizacji biznesplanu politycznego (przed, w trakcie i po zakończeniu kadencji) może zostać oszacowana albo na podstawie syntetycznego wskaźnika demokracji, opierającego się na agregacji różnych wymiarów rozwoju, mających zobrazować zmiany ilościowe i jakościowe, albo ich poszczególnych wskaźnikach, jakie dotychczas zostały opracowane. Należy zauważyć, że powszechny wskaźnik PKB ma swoje zasadnicze ograniczenia, niejednokrotnie podkreślane w literaturze, dlatego w celu kompleksowej oceny należy stosować znacznie szerszy wachlarz wskaźników, które mają znaczenie dla rozwoju społeczno-gospodarczego. Natomiast sam rozwój musi być zauważalny również z perspektywy obywatela i znajdować 
odzwierciedlenie $\mathrm{w}$ różnych miarach. W literaturze można znaleźć wiele propozycji pomiaru rozwoju społeczno-gospodarczego, np. wskaźnik zadowolenia z życia, wskaźnik rozwoju społecznego HDI, wskaźnik nierówności społecznej, wskaźnik społeczeństwa obywatelskiego, wyniki rankingu Banku Światowego Doing Business, czy wskaźniki z globalnego raportu konkurencyjności itd. Najważniejsze jednak, aby ocena sytuacji społeczno-gospodarczej była dokonywana na podstawie kompleksu miar, gdyż tylko wtedy można zaobserwować różne jego aspekty. Powyższa propozycja opiera się na biznesowym rozwiązaniu w zakresie kluczowych wskaźników efektywności (ang. Key Performance Indicators - KPI) wskazujących czy podjęte działania zbliżają do osiągnięcia określonego celu.

Z powyższym zagadnieniem związana jest kolejna propozycja, aby wysokość wynagrodzenia posłów (a także senatorów) uzależnić od miar społeczno-gospodarczych. Obecnie posłowie nie mają dostatecznej motywacji do skutecznego rządzenia, gdyż zawsze mają stałe wynagrodzenie, dlatego należy wprowadzić minimalne wynagrodzenie, a dużo wyższe zależne od syntetycznego wskaźnika demokracji lub ich poszczególnych miar, o czym była mowa wcześniej. Koncepcja nie jest nowa, gdyż od wielu lat jest wykorzystywana przez świat biznesu do wynagradzania za rzeczywiste efekty pracy (stałe wynagrodzenie podstawowe oraz premia w zależności od efektów pracy). Rozwiązanie $\mathrm{z}$ jednej strony motywuje pracownika do efektywnej pracy, a z drugiej pozwala lepiej kontrolować postępy $\mathrm{w}$ realizacji założonych celów organizacji. Nie bez znaczenia w tym kontekście jest również aspekt psychologiczny, wskazujący że osoba jest najbardziej produktywna i skuteczna na początku rozpoczęcia pracy, a następnie w miarę upływu czasu traci zapał, co przekłada się na uzyskiwane coraz słabszych efektów. Dlatego postuluje się kolejne rozwiązanie. Należy ograniczyć zjawisko zawodowych polityków, wiele lat funkcjonujących w świecie polityki, którzy poprzez swoją rozpoznawalność, koligacje i sieci współpracy, jakie się wytworzyły w ciągu lat ich pracy, a nie dzięki wiedzy i umiejętności w sprawnym sprawowaniu władzy, utrzymują się na rynku politycznym. Wielokrotnie wykorzystując różne segmenty sektora publicznego (samorząd, rząd, spółki skarbu państwa), aby przez wiele lat funkcjonować $\mathrm{w}$ polityce nie wnosząc za wiele do rozwoju gospodarki i kraju lub stosując metodę trampoliny - najpierw samorząd, a później władza 
rządowa. W celu urzeczywistnienia koncepcji skuteczniejszego sprawowania władzy należy przyjąć, że biznesplan polityczny będący propozycją rozwoju społeczno-gospodarczego, a także partia i jej nazwa z złożenia powinna być projektowa (chwilowa). Oznacza to na przykład, że nazwa nie powinna się powtarzać, aby zniwelować tendencje do ciągłego głosowania obywateli na tę samą partie, niezależnie od tego co robi. Wynika to z faktu, że obywatele nie mają możliwości podejmowania ekonomicznych i racjonalnych wyborów o charakterze publicznym, gdyż nie mają specjalistycznej wiedzy. Dlatego, na podstawie społecznego podziału pracy i specjalizacji pracy, obywatele zakładająi ufaja, że pretendenci do władzy czy też obecni przedstawiciele władzy mają bardzo wysoką i specjalistyczną wiedzę, są najlepszymi osobami mogącymi podjąć działania mające poprawić sytuację w kraju. Jednak, jak pokazuje praktyka, jest to nieprawda, gdyż obecna forma polityki opiera się na ideologii, partykularnych interesach partii, podejściu światopoglądowym oraz emocjonalnym, nie zaś na wiedzy merytorycznej i danych. W kontekście wcześniej przytoczonych propozycji zmian systemu demokracji szczególnego wydźwięku nabiera wypowiedź Janusza Lewandowskiego, który zapytany o sytuację fiskalną Polski wprost stwierdza, że „wszystkie bardziej radykalne reformy są jednak politycznym samobójstwem". Ponadto zaznaczył, że „źle kończyli nawet «Ci» wtedy, gdy reformy były zgodne z polską racją stanu" (Zybertowicz 2010, s. 39). Warto w tym miejscu zaznaczyć, że

Wyniki badań empirycznych, przeprowadzonych przez EBOiR, potwierdzają dodatnią zależność między stopniem zaawansowania reform a konkurencyjnością systemu politycznego. Częste zmiany rządu sprzyjają postępom $\mathrm{w}$ reformach (utrudniają powstawanie stosunków opartych na klientyzmie) (Przesławska 2006, s. 41-42).

Usprawnieniem wyborczym byłaby rezygnacja z głosowania na osoby z danej partii na rzecz głosowania wyłącznie na partie podczas wyborów. Propozycja jest znów wzięta wprost z konkurencyjnego rynku dóbr i usług, gdzie obywatele wybierają je pod względem swoich preferencji i własnych ograniczeń (np. budżetowych), nie mając wpływu na to, kto w danej firmie pracuje i za co odpowiada. Tak samo na rynku politycznym obywatele wybierają biznesplan polityczny (wizja rozwoju oraz działań podejmowanych w przyszłości), 
będący wyrazem powstania i egzystencji projektowej (chwilowej) partii politycznej. Powyższe rozwiązanie ograniczyłoby z jednej strony problemy na karcie do głosowania, które można było zaobserwować we wcześniejszych wyborach organizowanych przez PKW (zmniejszając jej rozmiary i upraszczając ją), a po drugie zmusiłoby obywateli do interesowania się biznesplanami politycznymi, dzięki ich łatwemu porównywaniu za pomocą gotowych rozwiązań informatycznych dostarczanych przez PKW, co zostało przedstawione $\mathrm{w}$ powyższych propozycjach. Zmiana reguł funkcjonowania wyborów będzie wpływać na powstanie nowych wzorców zachowań obywateli. Biorąc pod uwagę modele zachowań i upodobania obserwowane u użytkowników zakupów internetowych, można domniemywać, że podobne pozytywne wzorce (bierny konsument stał się aktywnym prosumentem) wystąpią również w przestrzeni wyborczej. Natomiast dzięki temu partia miałaby większą swobodę wyboru osób na konkretne stanowiska.

Najbardziej radykalną zmiana, ale podyktowaną przesłankami merytorycznymi, jest ograniczenie liczby kandydatów w wyborach politycznych, stosując rozwiązania dostępne $\mathrm{w}$ praktyce gospodarczej. Nie jest to sensu stricto ograniczenie biernych praw wyborczych, a jedynie sensu largo odpowiednia selekcja kandydatów, dających rękojmię z jednej strony skutecznego i efektywnego wykonywania prac wpływających na dobrobyt społeczeństwa, a braku marnotrawstwa zasobów z drugiej strony. Kandydaci na „polityków” muszą być ekonomistami lub przynajmniej mieć wiedzę ekonomiczna, gdyż rozwój nauki tak został usystematyzowany, że różne dziedziny zajmują się odmiennymi lub tymi samymi zagadnieniami, ale $z$ innej strony (perspektywy). Nauki ekonomiczne z definicji zajmują się badaniem tego, jak społeczeństwo wykorzystuje swoje ograniczone zasoby, aby w jak najlepszym stopniu zaspokoić swoje zróżnicowane potrzeby. Warto zaznaczyć, że ekonomia nie jest chrematystyka, która skupia się na zarabianiu pieniędzy, a nauką dotyczącą gospodarowania, mająca za cel poprawę życia ludzi. Osoby będące lekarzami, prawnikami lub zajmujące się innymi profesjami mogą być wybitnymi specjalistami w swojej dziedzinie, ale nie ekonomistami, a przez to już mają ograniczone możliwości rozwiązywania problemów przy wykorzystaniu nauk ekonomicznych. Należy w tym miejscu podkreślić, że we wszystkich obszarach działalności społeczno-gospodarczej, oprócz 
wyborczej (politycznej), od osób świadczących prace wymagane jest, aby posiadały odpowiednią wiedzę merytoryczną i kompetencje, a częstokroć niezbędne kwalifikacje (albo uprawnienia), bez których nie można wykonywać niektórych prac lub zawodów (np. lekarz, inżynier budownictwa itd.). Z nieznanych powodów sfera polityczna została wyłączona z tych wymagań, jakie musi mieć każdy pracujący, choć politycy mają zdecydowanie większy wpływ na funkcjonowanie branż czy nawet całych sektorów (np. wprowadzając odpowiednie regulacje prawne, wyznaczając kierunki rozwoju kraju itd.) niż przeciętny obywatel. Jednak to od zwykłego pracującego obywatela wymaga się zdecydowanie większego wachlarza wiedzy, kompetencji i kwalifikacji niż od polityka. Interesujący jest fakt, że w skali mikroekonomicznej, tzn. pojedynczego podmiotu, zgodnie z art. 19 ustawy z dnia 16 grudnia 2016 roku o zasadach zarządzania mieniem państwowym (ustawa o zasadach zarządzania mieniem państwowym, 2016), wskazuje się katalog wymagań (np. odpowiednie kierunkowe wykształcenie) w stosunku do kandydata na członka organu nadzorczego w spółce z udziałem Skarbu Państwa, a w skali makroekonomicznej, tj. polityka zarządzającego jednym z działów sektora publicznego (np. opieki zdrowotnej, nauki, energetyki, itd.), takich wymagań nie ma, choć może on jednocześnie wpływać na wiele podmiotów gospodarczych i instytucji publicznych. Dlatego tym bardziej dziwi brak odpowiednich regulacji prawnych i rozwiązań systemowych w tym zakresie.

Wprowadzenie głosowania elektronicznego dałoby społeczeństwu dwie kolejne korzyści, które nie były uprzednio dostępne. Obecnie społeczeństwo nie ma narzędzi oceny czy wpływu na podejmowane decyzje rządzących, gdyż nie każdemu wyborcy będzie się podobał w $100 \%$ polityczny biznesplan, a w trakcie kadencji nie ma narzędzia wyrażenia sprzeciwu. Natomiast gdy rząd przedstawi kilka opcji rozwiązania kwestii społecznych czy gospodarczych do wyboru, wówczas obywatele będą mieli możliwość selekcji najlepszego rozwiązania z kilku alternatywnych opcji. Warto zwrócić uwagę

na fakt, że idea e-demokracji bezpośrednio łączy się z koncepcją demokracji deliberacyjnej. [...] Skupia się ona na sferze praktyki i poszukuje odpowiednio zaprojektowanego mechanizmu rozwiązywania konkretnych problemów, poprzez zasięganie opinii obywateli (szeroko rozumiane konsultacje społeczne) (du Vall, Walecka-Rynduch, 2011, s. 45). 
Drugą korzyścią z wdrożenia elektronicznego głosowania może być wprowadzenie możliwości odwołania władzy w trakcie kadencji, gdyż w rękach społeczeństwa obecnie nie ma takiego narzędzia. Rozwiązanie nawiązuje wprost do demokracji szwajcarskiej i jej uwarunkowań, z której można czerpać dobre praktyki. Oczywiście nie może być mowy o jednorazowym e-referendum odwołującym rząd w trakcie kadencji, gdy prowadziłoby to do chaosu i braku stabilności państwa, a o cyklu występujących po sobie głosowań obywateli w równych odstępach czasu (np. co pół roku) w danej kadencyjności parlamentu i spełnienia innych założeń, m.in. w zakresie frekwencji. Natomiast wiążąca decyzja odwołująca obecną władzę mogłaby dopiero wystąpić po minimum trzech następujących po sobie negatywnych wynikach e-referendów. Przeprowadzenie jedynie pojedynczego e-referendum po wprowadzeniu niepopularnych rozwiązań (np. podatkowych) mogłoby niekorzystanie wpływać zarówno na sprawczość władzy, która nie podejmowałby koniecznych reform, jak i zniekształcałaby obraz działań polityków w oczach społeczeństwa jedynie przez pryzmat konkretnego rozwiązania prawnego, a nie realizowanej strategii i kierunków rozwoju kraju przez daną partie polityczną.

\section{PODSUMOWANIE}

Z przytoczonych problemów obecnego modelu demokracji, a także zaproponowanych kierunków zmian wynika, że społeczeństwo od wielu lat, w mniejszym lub większym stopniu, odczuwa straty korzyści gospodarczych (społeczno-ekonomicznych), wynikających z podjętych przez polityków decyzji lub ich zaniechania. Różnica między obecnym modelem demokracji a stanem optymalnym, którego oczekuje społeczeństwo (przyjmując domniemanie wynikające z badań CBOS), stanowi stratę cywilizacyjną. W związku z powyższym należy zmienić obecny model demokracji i wdrożyć zasady usprawniające działanie państwa w sferze polityki, korzystając przy tym m.in. z szans rozwojowych i cywilizacyjnych ( $w$ tym technologii ICT), a także bogatych doświadczeń świata biznesu, który od lat poszukuje i wdraża coraz to nowsze koncepcje zmniejszające koszty i usprawniające przedsiębiorstwa w różnych aspektach działalności. 
W niniejszym artykule przedstawiono tylko wybrane zagadnienia związane z wyborem $\mathrm{w}$ warunkach demokracji, w związku z powyższym przyszłe kierunki badań powinny rozszerzyć problematykę badawcza, uwzględniając m.in. tematykę sektora publicznego, w tym zagadnienie administracji publicznej i finansów publicznych.

\section{Bibliografia}

Barth, T.D., Schlegelmilch, W. (2014). Cyber Democracy: The Future of Democracy? W: E.G. Carayannis, D.F.J Campbell, M.P. Efthymiopoulos (red.), Cyber-Development, Cyber-Democracy and Cyber-Defense. Challenges, Opportunities and Implications for Theory, Policy and Practice (s. 195-206). New York: Springer.

Bochenek, M. (2010). Bruno S. Frey i Joseph E. Stiglitz o zawodności państwa i zawodności rynku. Ekonomia i Prawo, 6, 71-85.

Carayannis, E.G. (2014). Cyber-Development, From Development as Democracy to Innovation as Development. W: E.G. Carayannis, D.F.J. Campbell, M.P. Efthymiopoulos (red.), Cyber-Development, Cyber-Democracy and Cyber-Defense. Challenges, Opportunities and Implications for Theory, Policy and Practice (s. 1-22). New York: Springer.

CBOS (2018). O nieufności i zaufaniu. Komunikat z badań nr 35/2018.

CBOS (2019a). Polacy o demokracji. Komunikat z badań nr 68/2019.

CBOS (2019b). Oceny działalności parlamentu, prezydenta, PKW i Kościoła rzymskokatolickiego. Komunikat z badań nr 82/2019.

CBOS (2019c). Ocena funkcjonowania demokratycznych mechanizmów i procedur wyborczych w Polsce. Komunikat z badań nr 89/2019.

CBOS (2019d). Które zawody poważamy? Komunikat z badań nr 157/ 2019.

Contucci, P., Omicini, A., Pianini, D., Sîrbu, A. (2019). The Future of Digital Democracy. An Interdisciplinary Approach. Cham: Springer.

du Vall, M., Walecka-Rynduch, A. (2011). Netarchia jako propozycja modelu demokracji przyszłości. W: M. du Vall, M. Majorek, A. Walecka-Rynduch (red.), Wspótczesna przestrzeń polityczna. Ewolucja czy rewolucja? (s. 39-60). Kraków: Oficyna Wydawnicza AFM.

Gilejko, L.K (2012). Trzy wymiary demokracji: polskie problemy. W: Ł. Danel, J. Kornaś (red.), Dylematy polskiej demokracji (s. 59-73). Kraków: Fundacja Gospodarki i Administracji Publicznej.

Grzybek, D. (2007). Recenzja. Zarzadzanie Publiczne, 3, 169-173.

GUS (2019a). Społeczeństwo informacyjne w Polsce w 2019 r. 
GUS (2019b). Społeczeństwo informacyjne w Polsce Wyniki badań statystycznych z lat 2015-2019.

Guzik, T. (2017). Ekonomiczna analiza prawa jako metoda prawoznawstwa. Internetowy Przeglad Prawniczy TBSP UJ, 8(38), 25-36.

Hauptmann, E. (1996). Putting Choice Before Democracy: A Critique of Rational Choice Theory. Albany: State University of New York Press.

Hindman, M. (2009). The Myth of Digital Democracy. Princeton: Princeton University Press.

Legiędź, T. (2013). Nowa ekonomia instytucjonalna a zmiany paradygmatu rozwoju gospodarczego. Ekonomia, 4 (25), 77-91.

Lerner, J. (2014). Making Democracy Fun. How Game Design Can Empower Citizens and Transform Politics. London: Massachusetts Institute of Technology.

Lindner, R., Aichholzer, G. (2020). E-Democracy: Conceptual Foundations and Recent Trends. W: L. Hennen, I. Van Keulen, I. Korthagen, G. Aichholzer, R. Lindner, R.Ø. Nielsen (red.), European E-Democracy in Practice (s. 11-45). Cham: Springer.

Lissowski, G. (2010). Uzasadnienia metod wyboru społecznego. Decyzje, 14, 5-32.

Mancini, P. (2015). Why it is time to redesign our political system. European View, 14, 69-75.

Metelska-Szaniawska, K. (2012). Ekonomia konstytucyjna - ekonomia polityczna ładu gospodarczego. W: J. Wilkin (red.), Teoria wyboru publicznego. Główne nurty i zastosowania (s. 109-135). Warszawa: Wydawnictwo Naukowe SCHOLAR.

Metelska-Szaniawska, K., Olender-Skorek, M. (2012). Ekonomia i polityka regulacji. W: J. Wilkin (red.), Teoria wyboru publicznego Główne nurty i zastosowania (s. 238-272). Warszawa: Wydawnictwo Naukowe SCHOLAR.

Michalak, T. (2012). Ekonomiczna teoria demokracji Anthony'ego Downsa. W: J. Wilkin (red.), Teoria wyboru publicznego Główne nurty i zastosowania (s. 90-108). Warszawa: Wydawnictwo Naukowe SCHOLAR.

Ministerstwo Cyfryzacji (2020). E-ustugi w administracji. https://www. gov.pl/web/cyfryzacja/e-uslugi

Musiał-Karg, M. (2020). Elektroniczne głosowanie w opiniach Polaków. Postawy i poglady na temat e-voting. Poznań: Wydawnictwo Naukowe Wydziału Nauk Politycznych i Dziennikarstwa UMK.

Ogonowski, A. (2018). Udział grup interesu w publicznych procesach decyzyjnych. Tarnowskie Colloquia Naukowe, 5, 85-101.

Olson, M. (2012). Logika działania zbiorowego. Dobra publiczne i teoria grup, tłum. S. Szymański. Warszawa: Wydawnictwo Naukowe SCHOLAR. 
Przesławska, G. (2006). Ekonomiczna rola państwa w ujęciu nowej ekonomii politycznej. Ekonomia i Prawo, 2, 35-48.

Rezolucja Parlamentu Europejskiego z dnia 16 marca 2017 r. w sprawie e-demokracji w Unii Europejskiej: potencjał i wyzwania (2016/2008(INI)). Pobrano z: https://eur-lex.europa.eu/legal-content/ PL/TXT/?uri=CELEX:52017IP0095

Sell, F.L., Tkaczyński, J.W. (2011). Racjonalność wyborcy według ekonomicznej teorii demokracji Anthony'ego Downsa. Przeglad Prawa Konstytucyjnego, 3, 49-65.

Stiglitz, J.E. (2004). Ekonomia sektora publicznego. Warszawa: Wydawnictwo Naukowe PWN.

Tvaronaviciene, M., Burinskas, A. (2020). Industry 4.0 Significance to competition and the EU competition policy. Economics and Sociology, 13(3), 244-258.

Urbaniak, K. (2018). Wybory jako demokratyczny sposób kreowania organów władzy publicznej a dobro wspólne. Ruch Prawniczy, Ekonomiczny i Socjologiczny, 1(80), 151-167.

Ustawa z dnia 16 grudnia 2016 r. o zasadach zarządzania mieniem państwowym. Dz.U. 2016 poz.2259 (2020) (Polska). http://isap.sejm.gov. pl/isap.nsf/download.xsp/WDU20200000735/U/D20200735Lj.pdf

Wilkin, J. (2012a). Koncepcja dobrze rządzonego państwa i uwarunkowania jej praktycznej realizacji. W: J. Wilkin (red.), Teoria wyboru publicznego Główne nurty i zastosowania (s. 273- 281). Warszawa: Wydawnictwo Naukowe SCHOLAR.

Wilkin, J. (2012b). Pogoń za rentą za pomocą mechanizmów politycznych. W: J. Wilkin (red.), Teoria wyboru publicznego Główne nurty i zastosowania (s. 221-237). Warszawa: Wydawnictwo Naukowe SCHOLAR.

Wilkin, J. (2012c). Teoria wyboru publicznego - homo oeconomicus w sferze polityki. W: J. Wilkin (red.), Teoria wyboru publicznego Główne nurty i zastosowania (s. 9-30). Warszawa: Wydawnictwo Naukowe SCHOLAR.

Zybertowicz, A. (2010). Polityczna pogoń za rentą jako zagrożenie dla spójności społecznej i modernizacji: (Część I: Perspektywa teoretyczna). Nierówności Społeczne a Wzrost Gospodarczy, 16, 32-52.

\section{Copyright and License}

This article is published under the terms of the Creative Commons Attribution - NoDerivs (CC BY- ND 4.0) License http://creativecommons.org/licenses/by-nd/4.0/ 